\title{
PERLINDUNGAN HUKUM TERHADAP PASIEN SEBAGAI KONSUMEN JASA PELAYANAN KESEHATAN
}

\author{
Asram A.T.Jadda \\ Fakultas Hukum \\ Universitas Muhammadiyah Parepare, Jalan Jenderal Ahmad Yani KM 6 Kota Parepare \\ Kode Pos 91113, Telpon : 0421-22757/Fax 0421-2554 Sulawesi Selatan Indonesia \\ Asram 77@yahoo.co.id/081230293103
}

\begin{abstract}
This research is about "legal protection for patient as health service consumer". It belongs ti the juridical normative research, describing the provisions in law and regulation, in relation to the fact in the field, then conducting analysis by comparing the existing ideal values in law and regulation with the fact in the field. Therefore, it conducted library research supported with field research provides knowledge on the difference between as sollen and das sein.The research conducts document study and field research. Document study is data collecting from bibliography such as law and regulation, book, magazine, document, and also articles relevant with this research tipic. Field research collects data by direct observation in the field to look for the relevant information througt direct using interview guideline and questionnaire. Respondents are selected using purposive sampling method.Generally, legal protection for medical patient in Faisal Islamic Medical Centre (RSI Faisal) Ujung Pandang is still low. It can be shown from the fact that medical action which may cause patient's health hazard or death are still untouched by law. Poor protection can also be seen from the difficulty to ask hospital/doctor/ medical personnel to be responsible for patient heath condition hazard or death because of doctor/medical personnel malpractice. Poor protection to the patien is caused by there is no equality before the law between doctor/medical personnel and patient. Poor protection to the patient also caused by the absence of malpractice act which is supposed to be the base for settling malpractice committed doctor/medical personnel.
\end{abstract}

Keyword : Legal protection, patient, health

Abstrak: Penelitian ini membahas tentang "perlindungan hukum bagi pasien sebagai konsumen
layanan kesehatan". Ini termasuk dalam penelitian normatif yuridis, yang menjelaskan ketentuan
dalam undang-undang dan peraturan, terkait dengan fakta di lapangan, kemudian melakukan analisis
dengan membandingkan nilai ideal yang ada dalam peraturan perundang-undangan dengan fakta di
lapangan. Oleh karena itu, penelitian perpustakaan yang didukung dengan penelitian lapangan
memberikan pengetahuan tentang perbedaan antara das sollen dan das sein.Penelitian ini melakukan
studi dokumen dan penelitian lapangan. Dokumen penelitian adalah pengumpulan data dari daftar
pustaka seperti peraturan perundang-undangan, buku, majalah, dokumen, dan juga artikel yang relevan
dengan tipika penelitian ini. Penelitian lapangan mengumpulkan data dengan pengamatan langsung di
lapangan untuk mencari informasi yang relevan secara langsung dengan menggunakan pedoman
wawancara dan kuesioner. Responden dipilih dengan metode purposive sampling.Umumnya
perlindungan hukum bagi pasien medis di Rumah sakit Islam Faisal Faisal (RSI Faisal) Ujung
Pandang masih rendah. Hal ini dapat ditunjukkan dari kenyataan bahwa tindakan medis yang dapat
menyebabkan bahaya kesehatan pasien atau kematian masih belum tersentuh oleh undang-undang.
Perlindungan yang buruk juga bisa dilihat dari sulitnya meminta petugas medis / dokter / medis untuk
bertanggung jawab atas bahaya kondisi kesehatan pasien atau kematian karena malpraktek dokter /
medis. Perlindungan yang buruk terhadap kesabaran ini disebabkan tidak adanya persamaan hukum
antara dokter / tenaga medis dan pasien. Perlindungan yang buruk terhadap pasien juga disebabkan 
oleh tidak adanya tindakan malapraktik yang seharusnya menjadi dasar penyelesaian malpraktek yang dilakukan dokter / petugas medis.

Kata Kunci: perlindungan kesehatan, pasien, kesehatan

\section{LATAR BELAKANG}

Hukum kesehatan eksistensinya masih sangat relatif baru, dalam perkembangan di Indonesia, semula di kembangkan oleh Fred Ameln dan Almarhum Prof. Oetama dalam bentuk ilmu hukum kedokteran. Perkembangan kehidupan yang pesat di bidang kesehatan dalam bentuk sistem kesehatan nasional mengakibatkan diperlukan pengaturan yang lebih luas, dari hukum kedokteran ke hal-hal yang berkaitan dengan kesehatan (hukum kesehatan).

Hukum kesehatan yang ada di Indonesia dewasa ini tidak dapat lepas dari sistem hukum yang dianut oleh suatu Negara dan atau masyarakat, maka ada 2 (dua) sistem hukum di dunia yang dimaksud adalah sistem hukum sipil kodifikasi dan sistem hukum kebiasaan common law system. Kemudian di mungkinkan ada sistem hukum campuran, khusus bagi suatu masyarakat majemuk (Pluralistik) seperti Indonesia memungkinkan menganut sistem hukum campuran. Sehubungan dengan hal tersebut, maka dalam rangka memberikan kepastian dan perlindungan hukum, baik bagi pemberi jasa pelayanan kesehatan maupun bagi penerima jasa pelayanan kesehatan, untuk meningkatkan, mengarahkan dan memberikan dasar bagi pembangunan di bidang kesehatan diperlukan adanya perangkat hukum kesehatan yang dinamis. Banyak terjadi perubahan terhadap kaidah-kaidah kesehatan, terutama mengenai hak dan kewajiban para pihak yang terkait di dalam upaya kesehatan serta perlindungan hukum bagi para pihak yang terkait.

Selanjutnya apabila dilihat dari hubungan hukum yang timbul antara pasien dan rumah sakit dibedakan pada dua macam perjanjian yaitu: pertama, Perjanjian perawatan dimana terdapat kesepakatan antara rumah sakit dan pasien bahwa pihak rumah sakit menyediakan kamar perawatan dan dimana tenaga perawatan melakukan tindakan perawatan. Kedua, Perjanjian pelayanan medis di mana terdapat kesepakatan antara rumah sakit dan pasien bahwa tenaga medis pada rumah sakit akan berupa secara maksimal untuk menyembuhkan pasien melalui tindakan medis Inspannings Verbintenis ${ }^{1}$ Perlindungan terhadap pasien mendapatkan perhatian yang cukup, namun sangat di

\footnotetext{
1 Fred Ameln, 1991, Kapita Selekta Hukum Kesehatan, (Jakrta: Grafikatama Jaya) 1991, hlm .75-76.
} 
sayangkan kaidah-kaidah dasar dalam Undang-undang Nomor 23 Tahun 1992 tentang Kesehatan, yang memerlukan peraturan pelaksanaan sampai akhir abad ke 20 dan memasuki abad ke 21, masih belum mendapatkan realisasinya, karena pemerintah cq depertemen Kesehatan RI sampai saat ini baru sanggup membuat beberapa peraturan pelaksanaan antara lain Peraturan Pemerintah NO. 32 Tahun 1996 tentang Tenaga Kesehatan.

Rumah sakit dalam menjamin perlindungan hukum bagi dokter/tenaga kesehatan agar tidak menimbulkan kesalahan medik dalam menangani pasien, sekaligus pasien mendapatkan perlindungan hukum dari suatu tanggungjawab rumah sakit dan dokter/tenaga kesehatan.

Dalam kaitan dengan tanggungjawab rumah sakit, maka pada prinsipnya rumah sakit bertanggungjawab secara perdata terhadap semua kegiatan yang dilakukan oleh tenaga kesehatan sesuai dengan bunyi pasal 1367 (3) KUHPerdata. Selain itu rumah sakit juga bertanggungjawab atas wanprestasi dan perbuatan melawan hukum (1243, 1370, 1371, dan 1365 KUHPerdata) ${ }^{2}$

Peran dan fungsi rumah sakit sebagai tempat untuk melakukan pelayanan kesehatan (YANKES) yang

\footnotetext{
${ }^{2}$ Ibid.
}

profesional akan erat kaitannya dengan 3 (tiga) unsur yaitu: pertama, Unsur mutu yang di jamin kualitasnya; kedua, Unsur keuntungan atau manfaat yang tercermin dalam mutu pelayanan; dan terakhir Hukum yang mengatur perumahsakitan secara umum dan kedokteran dan/atau medik khususnya ${ }^{3}$.

Penulis berpendapat bahwa unsurunsur itu akan bermanfaat bagi pasien dan dokter/tenaga kesehatan serta rumah sakit, disebabkan karena adanya hubungan yang saling melengkapi unsur tersebut. Pelayanan kesehatan memang sangat membutuhkan kualitas mutu pelayanan yang baik dan maksimal, dengan manfaat yang dapat dirasakan oleh penerima jasa pelayanan kesehatan (pasien) dan pemberi jasa pelayanan kesehatan (dokter/tenaga kesehatan dan rumah sakit).

Dalam hal ini dokter dan tenaga kesehatan lainnya perlu memahami adanya landasan hukum dalam transaksi terapuitik antara dokter dengan pasien (kontrak terapetik), mengetahui dan memahami hak dan kewajiban pasien serta hak dan kewajiban dokter dan adanya wajib simpan

\footnotetext{
3 Hermain Hadiati Koeswadji, Beberapa Permasalahan Hukum dan Medik, (Bandung: PT. Citra Aditya Bakti,1992) Hlm.118.
} 


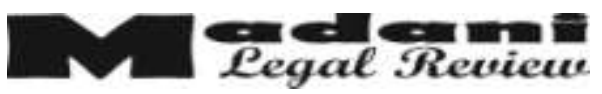

rahasia kedokteran, rahasia jabatan dan pekerjaan $^{4}$

Dinamika kehidupan masyarakat juga berlangsung pada aspek kesehatan, sehingga kadang muncul kelalaian dan terbengkalainya hak dan kewajiban antara pasien dengan dokter/tenaga kesehatan. Kesalahan dan atau kelalaian yang dilakukan oleh seorang dokter/tenaga kesehatan, dapat dituntut secara pidana apabila memenuhi unsur-unsur pidana, dalam hukum pidana dikenal kata "schuld" yang mengandung selain dari dolus dan kesalahan dalam arti yang lebih sempit adalah culpa, merupakan unsur esensial dalam suatu tindakan pidana agar dapat dimintakan pertanggungjawaban secara pidana.

Sebagai kesalahan tadi, culpa misalnya, ia mengandung 2 (dua) unsur ataupun persyaratan, yaitu : pertama, Kurang hati-hati, kurang waspada dan kurang "voorzichtig". Kedua, Kurang menduga timbulnya perbuatan dan akibat (kurang dapat "voorzien"). ${ }^{5} \quad$ Suatu hubungan kausal yang lebih merupakan kesalahan profesi dokter, dan dapat dipertanggungjawabkan karena tidak memenuhi kewajiban dan dapat

4 M. Jusuf Hanafiah dan Amri Amir,: Etika Kedokteran dan Hukum Kesehatan, (Jakarta: Penerbit Buku Kedokteran, 1999), hlm. 29.

${ }^{5}$ Oemar Seno Adji, , Etika Profesional dan Hukum Pertanggungjawaban Pidana Dokter Profesi Dokter,( Jakarta: Penerbit Erlangga, 1991) hlm.125. dikategorikan sebagai perbuatan melawan hukum.

Jika pasal 322 KUHP dapat memidanakan seorang dokter karena melanggar kewajibannya untuk merahasiakan apa yang menjadi pengetahunnya, maka Kode Etik Kedokteran Indonesia tersebut. Disebut pula Peraturan Pemerintah Nomor 20 tahun 1966 dimana Menteri Kesehatan dapat mengambil tindakan administratif terhadap seorang dokter yang tidak dapat dipidanakan berdasarkan pasal 322 KUHP $^{6}$ Apabila terjadi penyimpangan dalam ketentuan pelayanan kesehatan, pasien atau penerima jasa pelayanan kesehatan dapat menuntut haknya, yang di langgar oleh pihak penyedia jasa pelayanan kesehatan dalam hal ini rumah sakit dan dokter/tenaga kesehatan. Masih terdapat peraturan-peraturan pidana lainnya bersangkutan dengan kesalahan/kelalaian dari seorang dokter/tenaga kesehatan seperti pasal 351, 356 KUHP mengenai penganiayaan, dimana penganiayaan tersebut dianalogikan dengan sengaja merusak kesehatan dan pasal 359, 360 dan 378 KUHP mengenai tindak penipuan, serta pasal 512 KUHP mengenai kejahatan terhadap ketertiban umum.

Dokter/tenaga kesehatan dan rumah sakit dapat memintakan tanggungjawab

\footnotetext{
${ }^{6}$ Ibid.
} 


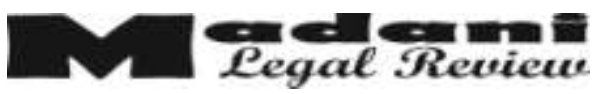

hukum, apabila melakukan kelalaian/ kesalahan yang menimbulkan kerugian bagi pasien sebagai konsumen jasa pelayanan kesehatan. Pasien dapat menggugat tanggungjawab hukum kedokteran (medical liability), dalam hal dokter berbuat kesalahan/kelalaian. Dokter tidak dapat berlindung dengan dalih perbuatan yang tidak sengaja, sebab kesalahan/kelalaian dokter yang menimbulkan kerugian terdapat pasien menimbulkan hak bagi pasien untuk menggugat ganti rugi ${ }^{7}$.

Pasien sebagai penerima jasa pelayanan kesehatan (konsumen) dengan dokter/tenaga kesehatan serta rumah sakit sebagai pemberi jasa pelayanan kesehatan (produsen) terikat dalam sebuah perjanjian yang terjadi antara kedua belah pihak. Berdasarkan pasal 1313 KUHPerdata perjanjian adalah "suatu perbuatan dengan mana satu orang atau lebih mengikatkan dirinya terhadap satu orang lain atau lebih". Untuk adanya suatu perjanjian harus ada dua kehendak yang mencapai kata sepakat atau consensus. Tanpa kata sepakat tidak mungkin ada perjanjian ${ }^{8}$.

\footnotetext{
${ }^{7}$ Wila Chandrawila Supriadi, Hukum Kedokteran, (Bandung: Penerbit CV. Mandar Maju, 2001) hlm. 31 .

${ }^{8}$ Sudikno Mertokusumo, Mengenal Hukum Suatu Pengantar, (Yogyakarta: Penerbit Liberty, 1999) hlm. 111.
}

Kata sepakat dan konsensus mengandung pengertian bahwa para pihak saling menyatakan kehendak masingmasing untuk membuat suatu perjanjian, dimana kehendak pihak yang satu sesuai dengan kehendak pihak yang lain secara timbal balik.

Antara pasien sebagai penerima jasa pelayanan kesehatan (konsumen) dengan dokter/tenaga kesehatan serta rumah sakit sebagai pemberi jasa pelayanan kesehatan (produsen) terjadi kesepakatan untuk melakukan tindakan medik, sehingga ada dikenal istilah perjanjian penyembuhan atau yang sering disebut transaksi terapeutik. Jadi perjanjian terapeutik sama dengan perjanjian penyembuhan.

Perjanjian terapeutik atau perjanjian penyembuhan menurut Veronika Komalawati :"hubungan antara dokter dan pasien dalam pelayanan medik secara profesional didasarkan kompetensi yang sesuai dengan keahlian dan keterampilan tertentu di bidang kedokteran"9

Perjanjian terapeutik (transaksi terapeutik) apabila dikategorikan sebagai perjanjian pemberian jasa yang didasarkan atas hubungan pelayanan dengan kepercayaan dan prinsip pemberian

\footnotetext{
${ }^{9}$ Veronica K, Peranan Informent Consent dalam Transaksi Terapeutik (Persetujuan dalam Hubungan Dokter dan Pasien) Suatu Tinjauan Yuridis, (Bandung: Citra Aditya Bakti, 2002) hlm .14 .
} 


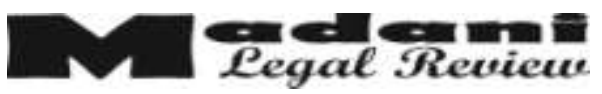

pertolongan, sehingga terjadi hubungan pemberian pertolongan medik. Pemberi jasa pelayanan kesehatan berupaya secara maksimal untuk menyembuhkan pasien (penerima jasa pelayanan kesehatan) bukan menjanjikan suatu hasil tertentu. Doktrin ilmu hukum mengenal dua macam perikatan, perikatan ikhtiar/upaya inspannings verbintenis dan perikatan hasil resultaats verbintenis. Pada perikatan ikhtiar maka prestasi yang harus diberikan oleh dokter adalah upaya semaksimal mungkin, sedangkan pada perikatan hasil prestasi yang harus diberikan oleh dokter berupa hasil tertentu. ${ }^{10}$

Perikatan yang terjadi antara pasien dan dokter/tenaga kesehatan serta rumah sakit menimbulkan hubungan hukum. Hubungan yang terjadi antara pasien dengan dengan rumah sakit adalah hubungan antara pasien sebagai subjek hukum konsumen jasa pelayanan kesehatan dan rumah sakit sebagai subjek hukum produsen jasa pelayanan kesehatan, antara pasien dengan rumah sakit terdapat aturan-aturan, atau kaidah-kaidah hukum perdata dan memenuhi hubungan tentang pengaturan hak dan kewajiban para pihak.

Hubungan dokter/tenaga kesehatan dan rumah sakit dengan pasien mempunyai aspek yuridis atau hukum, adapun aspek hukum yang urgen dalam hubungan itu

\footnotetext{
${ }^{10}$ Mertokusuma, Op cit, hlm 8
}

adalah hukum perikatan. Hubungan dokter dengan pasien merupakan suatu perikatan yang objeknya adalah berupa pelayanan medis atau upaya penyembuhan, yang dikenal dengan perjanjian terapeutik atau kontrak terapeutik. ${ }^{11}$

Pasien mempunyai kedudukan yang sama dengan dokter, dokter adalah warga Negara sebagai warga Negara dokter tidak boleh melanggar hukum, dokter tidak boleh melanggar hak atas pelayanan kesehatan, hak atas pelayanan kesehatan inilah yang mendasari adanya hubungan pasien dengan dokter. Hak atas pelayanan kesehatan menimbulkan kewajiban hukum melayani dari dokter, kewajiban ini tidaklah mutlak. Artinya dokter tidak wajib memberikan pertolongan kepada orang yang menolak pertolongan itu, hak ini dikenal dengan hak otonomi atas diri sendiri (pasien) $)^{12}$

Hak pasien adalah mendapatkan ganti rugi apabila pelayanan yang diterima tidak sebagaimana mestinya. Masyarakat sebagai konsumen dapat menyampaikan keluhannya kepada pihak rumah sakit sebagai upaya perbaikan interen rumah sakit dalam pelayanannya atau kepada lembaga yang member perhatian kepada

11 Husaien Kerbala, Segi-segi Etis dan Yuridis Informent Consent, (Jakarta: Pustaka Sinar Harapan, 1993) hlm. 38.

12 Bahar Azwar, Buku Pintar Pasien Sang Dokter, (Bekasi: Kesaint Blanc, 2001) hlm. 3. 


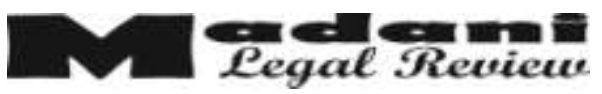

konsumen kesehatan. Sebagai dasar hukum dari gugatan pasien atau konsumen/penerima jasa pelayanan kesehatan terhadap dokter/tenaga kesehatan dan rumah sakit terdapat dalam pasal 1365 KUHPerdata.

Ketika pasien merasa dirugikan, pasien sebagai penerima jasa pelayanan kesehatan dan rumah sakit sebagai pemberi jasa pelayanan kesehatan dalam bidang keperawatan kesehatan. Maka dibutuhkan suatu perlindungan hukum, perlindungan hukum bagi pasien sebagai konsumen jasa pelayanan kesehatan. Dan rumah sakit berkewajiban untuk memberikan jasa pelayanan kesehatan sesuai dengan ukuran atau standar perawatan kesehatan.

Keluarga pasien dapat melayangkan gugatan terhadap Majelis Kode Etik Kedokteran (MKEK), dan pengadilan serta terhadap pihak yang terkait, karena merasa dirugikan dan diperlakukan tidak manusiawi. Maka dapat menggugat ganti rugi kepada pihak dokter/tenaga kesehatan dan rumah sakit karena telah melakukan perbuatan melawan hukum, dengan menimbulkan kerugian diakibatkan oleh kesalahan/kelalaian dalam melakukan tindakan medik.

Maka dibutuhkan perlindungan hukum bagi pasien (penerima jasa pelayanan kesehatan), yang senatiasa diabaikan haknya untk mendapatkan perawatan kesehatan. Undang-undang nomor 23 tahun 1992 tentang kesehatan memberikan perlindungan hukum, baik kepada pasien sebagai penerima (konsumen) jasa pelayanan kesehatan dan pemberi (produsen) jasa pelayanan kesehatan, diantaranya pasal 53, 54 dan 55 undang-undang nomor 23 tahun 1992. Jika terjadi sengketa antara para pihak dalam pelayanan kesehatan, maka untuk menyelesaikan sengketa atau perselisihan harus mengacu pada undang-undang kesehatan dan undang-undang perlindungan konsumen serta prosesnya melalui lembaga pengadilan dan mediasi.

Berdasarkan latar belakang masalah di atas dapat dirumuskan permasalahan sebagai berikut: Bagaimana perlindungan hukum terhadap pasien sebagai konsumen.

\section{METODE PENULISAN}

Penelitian ini merupakan penelitian yuridis normative yaitu suatu penelitian yang mengungkapkan suatu masalah, keadaan atau peristiwa dengan memberikan suatu penilaian secara menyeluruh, luas dan mendalam dari sudut pandang ilmu hukum, yaitu dengan meneliti asas-asas hukum, kaidah-kaidah hukum, dan sistematika hukum.

Dalam pengumpulan data digunakan studi dokumen yaitu dengan mempelajari bahan-bahan sekunder, baik berupa 


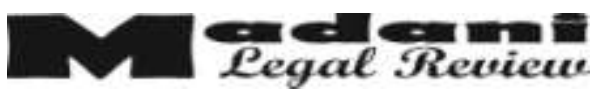

perundang-undangan, peraturan-peraturan lainnya, putusan pengadilan tentang kasuskasus kesehatan serta buku, makalah, dan jurnal berkaitan dengan yang diteliti. Selain itu digunakan metode wawancara langsung dan kuisioner. Wawancara dilakukan dengan mengajukan pertanyaan secara lisan berdasarkan pedoman pertanyaan yang sudah dipersiapkan kemudian dari pedoman tersebut dapat dikembangkan pertanyaan-pertanyaan tambahan untuk memperoleh keterangan secara lengkap dan menyeluruh. Kuisioner dilakukan dengan menggunakan daftar pertanyaan yang telah dibuat dan disusun secara terbuka dan tertutup. Pada pertanyaan yang bersifat terbuka responden diberikan kesempatan untuk menjawab pertanyaan secara bebas dan lengkap, sementara pada pertanyaan yang bersifat tertutup responden tidak mempunyai kesempatan untuk memberikan jawaban secara bebas.

Data yang diperoleh kemudian dianalisis secara kualitatif, yaitu suatu metode analisis data yang tidak berdasarkan pada angka-angka atau statistik, sehingga data yang diperoleh dalam penelitian kepustakaan digabungkan dengan data yang diperoleh dalam penelitian lapangan kemudian disajikan dalam kalimat-kalimat yang logis untuk memperoleh deskripsi tentang perlindungan hukum terhadap pasien sebagai konsumen jasa pelayanan kesehatan, terutama mengenai bagaimana perlindungan hukum terhadap pasien sebagai konsumen.

\section{PEMBAHASAN}

\section{Aspek Hukum Sistem Pelayanan dan Pembiayaan Kesehatan}

Segala bidang kehidupan memiliki aspek hukum tidak terkecuali pelayanan kesehatan. Aspek hukum sangat diperlukan untuk menengakkan hak dan kewajiban dokter-pasien. Hubungan yang terjadi antara dokter/tenaga kesehatan dengan pasien karena rasa tanggungjawab hukum, dan tanggungjawab profesi pada dasarnya ditujuhkan agar pihak pemberi jasa kesehatan harus berhati-hati supaya tidak terjadi kesehatan/malpraktek. Selain itu dengan adanya tanggungjawab hukum dan profesi diharapkan dapat mempengaruhi peningkatan mutu pelayanan kesehatan yang baik dan optimal.

Hal yang sangat penting dalam aspek hukum ini adalah ketika terjadi pelanggaran hak dan kewajiban dari masing-masing pihak. Hukum merupakan cara penyelesaian yang ditempuh terhadap pelanggaran itu. Dalam hal ini hukum sangat penting karena apabila tidak ada hukum, maka dapat terjadi kesewenangwenangan dari salah satu pihak, sedangkan 
apabila ada pelindungan hukum maka kedua belah pihak akan melaksanakan hak dan kewajibannya dengan baik.

Jika dilihat dari aspek hukum, maka hubungan antara rumah sakit dan pasien merupakan bentuk hubungan antara rumah sakit sebagai penyelenggara jasa kesehatan dan pasien sebagai pengguna jasa pelayanan kesehatan. Dalam prakteknya pelaksanaan jasa kesehatan dilakukan oleh dokter/tenaga kesehatan. Dokter berkewajiban untuk melaksanakan tugasnya membantu menyembuhkan pasien dengan segala ilmu dan pengetahuan yang dimilikinya, sebaliknya pasien sebagai pengguna jasa pelayanan kesehatan berkewajiban atas biaya administrasi yang berkaitan dengan pelayanan dokter dan rumah sakit.

Sering terdengar dalam praktek di masyarakat bahwa seorang pasien yang tidak mempunyai kemampuan untuk membayar biaya pelayanan kesehatan yang telah diterimanya kemudian 'disandera' pihak rumah sakit sampai ia dapat melunasi semua kewajibannya. Dilihat dari kepentingan rumah sakit sebagai penyelenggara kesehatan dapat dikatakan bahwa tindakan rumah sakit merupakan bagian dari upaya rumah sakit agar tidak dirugikan. Di lain pihak ditinjau dari kepentingan pasien selaku pengguna jasa kesehatan, tindakan tersebut merupakan bentuk 'pemaksaan' sistem rumah sakit untuk membayar biaya yang berat bagi mereka. Masalah lain tentang biaya pelayanan kesehatan yang sering dikeluhkan masyarakat adalah masalah mahalnya biaya kesehatan yang dianggap sangat adil bagi masyarakat Indonesia yang justru banyak didominasi oleh masyarakat kelas menengah ke bawah. Berikut akan dibahas mengenai aspek hukum dari pelayanan kesehatan dan masalah biaya kesehatan yang diuraikan diatas.

\subsection{Pelayanan Kedokteran dalam Perawatan Pasien}

Dalam bidang jasa pelayanan kesehatan/medik, pelayanan kesehatan dilakukan oleh dokter/tenaga kesehatan. Dokter wajib menggunakan seluruh keahlian, kepandaian, dan keterampilan yang dimilikinya untuk membantu semua pasien tanpa ada pengecualian. Kewajiban ini timbul karena ada kata Kesepakatan yang menjadi dasar terjadinya perjanjian terapeutik.

Menurut Hamzah Casa, untuk memberikan pelayanan kesehatan baik pihak Rumah Sakit Pemerintah maupun Rumah Sakit Swasta tidak boleh melakukan pembedaan pelayanan. Semua pasien dianggap sama berdasarkan aturan yang telah ditetapkan oleh pemerintah $\mathrm{Cq}$ Departemen Kesehatan dan aturan-aturan 


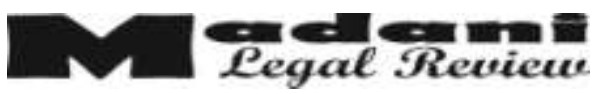

yang dibuat pihak RS sesuai ketentuan umum yang ada.

Hal senada dikemukakan M. Yusuf Saleh, untuk mengupayakan hasil pelayanan kesehatan yang baik terhadap pasien berdasarkan sistem pelayanan kesehatan maka pihak Rumah Sakit harus mengoptimalkan sistem itu, sesuai dengan prosedur tetap (protap) Rumah Sakit dan peningkatan terhadap sumber daya profesi masing-masing bidang keilmuan di dunia kedokteran.

Salah satu tujuan dari kode etik kedokteran, adalah untuk melindungi kepentingan pasien di samping mengembangkan kualitas profesi dokter atau tenaga kesehatan. Keserasian antara kepentingan pasien dan kepentingan dokter/tenaga kesehatan, merupakan salah satu penunjang keberhasilan pembangunan sistem pelayanan kesehatan. Oleh karena itu pelindungan hukum terhadap kepentingan-kepentingan itu harus diutamakan.

Di satu pihak pasien menaruh kepercayaan terhadap kemampuan professional dokter/tenaga kesehatan. Di lain pihak karena adanya kepercayaan tersebut seyogyanya dokter/tenaga kesehatan memberikan pelayanan kesehatan menurut standard profesi dan berpegang teguh pada kerahasiaan profesi.
Kedudukan dokter/tenaga kesehatan yang selama ini dianggap lebih "tinggi" dari pasien disebabkan keawanan pasien terhadap profesi kedokteran. Dengan semakin berkembangnya masyarakat, hubungan tersebut secara perlahan-lahan mengalami perubahan. Kepercayaan kepada dokter/tenaga kesehatan secara pribadi berubah menjadi kepercayaan terhadap keampuhan ilmu kedokteran dan teknologi. Agar dapat menanggulangi masalah secara professional dan mencegah apa yang dinamakan malpraktek di bidang kedokteran, perlu diungkap hak dan kewajiban pasien. Pengetahuan tentang hak dan kewajiban pasien diharapkan akan meningkatkan kualitas sikap dan tindakan yang cermat dan hati-hati dari dokter/tenaga kesehatan.

Seorang dokter/tenaga kesehatan mempunyai tugas mulia membantu kesembuhan pasien. Dalam melaksanakan tugasnya untuk membantu penyembuhan pasien itu hubungan dokter-pasien adalah hubungan antara penyedia jasa dan penerima jasa. Karenanya pasien berhak mengetahui segala macam tindakan yang dilakukan terhadap diri dan untuk apa tindakan itu dilakukan. Pengobatan terhadap diri pasien harus didiskusikan sedalam-dalamnya dengan dokternya. Hak dan kewajiban dokter, dan berhak serta kewajiban pasien harus sama-sama 
dihargai. Untuk bias mengaitkan kedua kepentingan dari dua pihak inilah ada yang disebut ' informed consent' yang sebenarnya ditunjukan untuk melindungi pasien, namun dalam perkembangan menjadi sering merugikan pasien karena dianggap 'tanda tangan dari pihak pasien bahwa kalau terjadi apa-apa nanti, dokter tidak bertanggungjawab'. Hal itu jelas tidak benar, karena pada intinya hal yang terkandung dalam informed consent adalah bentuk kewajiban dokter/tenaga kesehatan menginformasikan berbagai tindakan medis yang akan diambil dan diresikonya terhadap kesehatan/nyawa manusia, sehingga pihak pasien/keluarganya dapat mempertimbangkan dengan baik berbagai aspek yang terkait dengn sebaik-baiknya dan ditanyakan mana-mana yang mana masih belum jelas. Tegasnya, komunikasi antara pihak pasien dengan pihak dokter harus dibina lebih dulu sebelum dilakukan tindakan.

Jadi sesungguhnya yang terutama dalam informed consent adalah dokter wajib memberikan informasi kepada pasien/keluarganya dan selanjutnya meminta persetujuan kepada pasien/keluarganya mengenai tindakan medis yang akan dilakukan. Apabila setelah dikomunikasikan tenyata pasien/keluarganya tidak diperbolehkan tindakan medis tersebut walaupun tindakan itu merupakan satu-satunya cara mengobati pasien.

Ada juga situasi dimana pasien dirawat lama dan masih dalam kondisi kritis. Pada keadaan seperti ini sukar mengumpulkan seluruh keluarga setiap hari, apalagi banyak yang bekerja kantor, maka sebaiknya ditunjuk oleh keluarga seorang wakil yang selalu hadir menerima berbagai penjelasan-penjelasan dari hari ke hari tentang kemajuan pasien, tentang pemeriksaan, tentang obat, dan sebagainya. Wakil ini kemudian meneruskankepada keluarga, dan yang bersangkutan menjadi penghubung keluarga dan dokter/rumah sakit.

Mengenai informed consent masih diperlukan pengaturan hukum lebih lengkap. Karena hanya untuk melindungi pasien dari kewenangan dokter, tetapi juga diperlukan untuk melindungi dokter dari kesewenangan pasien yang melanggar batas-batas hukum dan perundangundangan.

Di dalam ketentuan informed consent diatur antara lain pada Peraturan Pemerintah No.18 Tahun 1981 dan Surat Keputusan PD IDI No.319/PB/A4/88. Pernyataan IDI tentang informed consent tersebut adalah:

Pertama, Manusia dewasa sehat jasmani dan rohani berhak sepenuhnya menentukan apa yang hendak dilakukan 
terhadap tubuhnya. Dokter tidak berhak melakukan tindakan medis yang bertentangan dengan kemauan pasien, walaupun untuk kepentingan pasien sendiri.

Kedua, Semua tindakan medis (diagnostic, terapeutik maupun paliatif) memerlukan informed consent secara lisan maupun tertulis.

Ketiga, Setiap tindakan medis mempunyai risiko cukup besar, mengharuskan adanya persetujuan tertulis yang ditandatanggangi pasien, setelah sebelumnya pasien memperoleh informasi yang kuat tentang perlunya tindakan medis yang bersangkutan serta risikonya.

Keempat, Untuk tindakan yang tidak termasuk dalam butir 3, hanya dibutuhkan persetujuan lisan atau sikap diam.

Kelima, Informasi tentang tindakan medis harusdiberikan kepada pasien, baik diminta maupun tidak diminta oleh pasien. Menahan informasi tidak boleh, kecuali bila dokter menilai bahwa informasi tersebut dapat merugikan kepetingan kesehatan pasien. Dalam hal ini dokter dapat memberikan informasi kepada keluarga terdekat dengan pasien, kehadiran seorang perawat/paramedic lain sebagai saksi adalah penting.

Keenam, Isi formasi mencakup keuntungan dan kerugian tindakan medis yang direncanakan, baik diagnostic, terapeutik maupun paliatif. Informasi biasanyandiberikan secara lisan, tetapi dapat pula secara tertulis (berkaitan dengan informed consent).

Menurut M. Yusuf Saleh, dapat diketahui bahwa jenis pelayanan kesehatan yang diberikan oleh RS kepada pasien secara umum terdiri dari rawat jalan dan rawat inap. Selain itu jenis pelayanan kesehatan yang lain juga dipersiapkan pihak Rumah Sakit untuk mendukung proses pelayanan kesehatan yang menyeluruh dan terpadu, antara lain rontgen, fhisioterapi, radiologi, laboratorium dan kamar operasi (ICU, ICCU). Pelayanan radiologi dan laboratorium dipergunakan untuk membantu diagnosis penyakit. Lebih lanjut beliau mengatakan bahwa dalam pelayanan terhadap pasien pihak RS dilakukan berdasarkan standard prosedur tetap (protap). Adapun kronologi dalam memberikan perawatan terhadap pasien adalah pasien harus mendaftarkan diri di tempat pendaftaran pasien rawat jalan (TP2RJ) kecuali bagi pasien gawat darurat dilakukan tindakan dulu baru kemudian keluarganya disuruh untuk mendaftaran pasien di tempat pendaftaran pasien di tempat pendaftaran. Perawatan dilakukan dengan dasar medik yang ada, jika indikasi medik memerlukan opname maka si pasien 


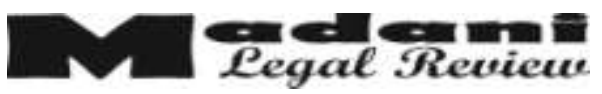

dirawat secara rawat jalan dan berakhir ketika kondisi pasien sudah merasa membaik atau sembuh menurut dokter yang merawatnya.

Selain itu pasien akan mendaptkan perawatan dari dokter/tenaga kesehatan yang ditunjuk untuk menangani pasien berdasarkan penyakit yang diderita pasien. Kadang ada pula pasien yang diopname dipoli dan ada yang tiak dirawat, karena hanya membutuhkan rawat jalan. Hal ini terjadi dengan adanya kesepakatan antara pihak RS dengan pasien.

Menurut Abu Bakar Betan, pelayanan kedokteran dilakukan seorang dokter/tenaga kesehatan harus selalu berdasarkan indikasi medis dan sesuai dengan prosedur tetap (protap) yang telah menjadi acuan dalam memberikan pelayanan kedokteran. Adapun contoh tindakan medis yang dilakukan dokter/tenaga kesehatan di Rumah Sakit yang membutuhkan prosedur tetap adalah tindakan operasi, infuse, suntikan dan perawatan. selama pasien menjalani perawatan dari Rumah Sakit, dokter/tenaga kesehatan diharuskan memberikan petunjuk mengenai hal-hal yang dianjurkan dan hal-hal yang dilarang dalam rangkah pengobatan pasien.

Hal senada diungkapkan Yusuf Saleh, dalam melakukan pelayanan kesehatan tersebut Rumah Sakit Islam
Faisal tidak membeda-bedakan pasien dalam hal perawatan medic. Semua pasien dianggap sama tanpa membedakan agama, ras, suku, bahkan status kemampuan ekonomi dari pasien. Pada prinsipnya Rumah Sakit harus melakukan pertolongan untuk menyelamatkan nyawa pasien.

Hal ini sejalan dengan pendapat yang dikemukakan oleh Hamzah Casa, yang menyatakan bahwa dalam memberikan pelayanan kesehatan Rumah Sakit Islam Faisal Ujung Pandang tidak mengenal klasifikasi golongan pasien yang datang berobat ke rumah sakit. Dalam hal ini Rumah Sakit memberikan penggolangan berdasarkan obat-obatan yang dipakai selama dirawat di Rumah Sakit Islam Faisal dan biaya perawatan berdasarkan pada kelas dimana pasien itu dirawat. Jika pasien pasien itu dirawat kelas IIIA maka status pasien dikategorikan golongan menengah ke bawah (miskin), dan apabila pasien dirawat pada kelas I, VIP Biasa dan VIP Utama maka status pasien itu dikategorikan sebagai golongan menengah keatas (kaya).

Apa yang dikemukakan Hamzah Casa diatas, juga sama dengan pendapat Abu Bakar Betan yang menyatahkan bahwa dalam memberikan pelayanan kesehatan RS Islam Faisal tidak mengenal klasifikasi golongan pasien yang datang ke Rumah Sakit untuk mendapatkan 
perawatan/pengobatan, namun dari segi fasilitas RS yang dipergunakan dan penggunaan obat-obatan selama proses penyembuhan di kenal penggolongan perincian biaya. Status sosial dan ekonomi tidak menjadi perhitungan untuk melakukan pertolongan terhadap pasien yang datang ke Rumah Sakit untuk berobat.

Dalam memberikan pelayanan kesehatan, pihak Rumah Sakit Islam Faisal memerintahkan semua unsur yang ada di Rumah Sakit, antara lain pengelola Rumah Sakit, dokter/tenaga kesehatan, perawat, premedis bahkan clening cervis dan satpam agar memberikan pelayanan yang terbaik kepada semua pasien dan keluarganya. Komunikasi antara pihak pengawas pelayanan kesehatan. Hal ini dilakukan untuk melakukan kualitas pelayanan kesehatan yang diberikan.

Menurut Abu Bakar Betan, dalam penyembuhan pasien, terdapat perjanjian kerjasama antara pihak di Rumah Sakit dalam rangka menyembuhkan pasien. Perjanjian itu dituangkan dalam bentuk perjanjian kerjasama (PKB) untuk mendukung pelayanan perawatan yang baik dan optimal. Sebagai contoh bagi pasien yang telah menjalani operasi harus dilakukan fisiotherapy untuk melatih fisik pasien. Untuk itu kerjasama antara dokter yang melakukan fisioterapi dengan dokter yang melakukan operasi dituangkan dalam perjanjian kerja bersama (PKB). Misalnya pengobatan pasien juga membutuhkan pengawasan gizi, maka PKB dilakukan pula dengan melibatkan dokter ahli gizi.

Uraian diatas menceritakan tentang prosedur standard dari Rumah Sakit Islam Faisal Ujung Pandang. Untuk mengetahui lebih lanjut mengenai pelaksanaan kewajiban rumah sakit dalam hal pelaksanaan informed consent penulis melakukan wawancara dengan Hamzah Casa yang merupakan pengelola Rumah Sakit Islam Faisal. Dari wawancara yang dilakukan diketahui bahwa masalah informed consent sudah dilaksanakan dalam praktek sehari-hari di Rumah Sakit Islam Faisal. Menurut dokter harus mendapatkan izin dari pasien sebelum melakukan tindakan medis kepada pasiennya. Hal ini dilakukan agar pasien mempertimbangkan dengan baik tentang segala kemungkinan yang akan terjadi dengan pengobatan yang dijalaninya. Dalam memberikan informasi yang berkaitan dengan penyakitnya itu dokter harus melakukan dengan tetap menghargai semua keputusan pasien, termasuk apabila pasien menolak dilakukan tindakan medis yang seharusnya ditempuh untuk pengobatan penyakitnya.

Menurut dr. Asvin Nurulita, dapat diketahui bahwa dalam tindakan medis ada 


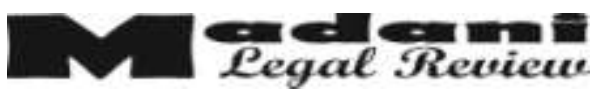

tiga jenis tindakan yang biasa dilakukan dokter dalam usaha menyembuhkan pasien, yaitu tindakan kecil, tindakan sedang dan tindakan besar. Contoh tindakan kecil yang dilakukan oleh dokter adalah menjahit luka si pasien. Contoh tindakan sedang adalah operasi. Contoh tindakan besar adalah pengangkatan tumor, kanker, dan lain-lain. Secara umum apabila tindakan yang dilakukan dokter hanya termasuk tindakan kecil, maka biasanya dokter langsung mengambil tindakan tanpa memberitahukannya terlebih dahulu kepada pasien. Tindakan ini dilakukan karena tindakan kecil itu sendiri secara umum tidak membahayakan nyawa pasien. Akan tetapi jika tindakan yang dilakukan itu termasuk tindakan sedang, apalagi jika termasuk tindakan besar, maka dokter harus memberitahukan dahulu sebelum melaksanakan tindakan itu kepada pasien dan/atau keluarga pasien. Hal ini dikarenakan tindakan sedang dan tindakan besar dapat membawa implikasi yang tidak diharapkan, misalnya pasien meninggal ketika mendapatkan tindakan medis. Oleh karena itu agar pasien dan/atau keluarga pasien siap menerima kemungkinan yang terjadi, maka sebelumnya harus diberitahukan terlebih dahulu kepada pasien dan/atau keluarganya mengenai tindakan medis yang akan dilakukan termasuk resiko-resiko yang menyertainya.
Menurut Direktur Rumah Sakit Islam Faisal, dr. Farid Husain, Sp.BD, dapat diketahui bahwa sistem penyelenggaraan pelayanan kesehatan di Rumah Sakit Islam Faisal Ujung Pandang, sudah sesuai dengan peraturan perundang-undangan yang ada berdasarkan Undang-Undang NO.23 Tahun 1992 tentang Kesehatan. Dengan alasan bahwa Rumah Sakit Islam Faisal Ujung Pandang mendapatkan status Akreditasi dari Departemen Kesehatan RI. Lebih lanjut dikatakan bahwa sistem pelayanan kesehatan harus dijalankan secara menyeluruh dan terpadu untuk mendukung tercapainya pelayanan kesehatan yang bermanfaat bagi masyarakat Indonesia. Dari uraian diatas diketahui bahwa dalam prakteknya pelaksanaan informed consent di Rumah Sakit Islam Faisal hanya dilakukan untuk tindakan medis sedang dan besar yang mempunyai risiko terhadap kesehatan pasien. Akan tetapi apabila tindakan medis yang dilakukan hanya tergolong tindakan kecil, maka biasanya dokter langsung melakukan tindakan medis tanpa menginformasikan sebelumnya kepada pasien dan/atau keluaraganya mengenai tindakan media yang akan dilakukan. Selain itu dapat pula bahwa secara umum pasien dan/atau keluarganya tidak mengetahui bahwa mereka mempunyai hak untuk mengetahui tindakan-tindakan medis 


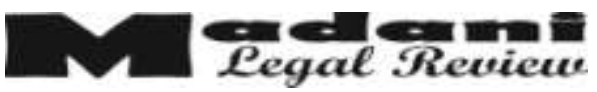

yang akan dilakukan terhadap diri/keluarganya. Dengan kata lain mereka tidak apa yang menjadi hak mereka. Bagi para pasien itu yang terpenting adalah bahwa mereka dapat sembuh dari penyakit yang dideritanya.

\subsection{Pembiayaan Kesehatan dalam} Upaya Pelayanan Kesehatan

Salah satu masalah yang paling sering dibicarakan dan menjadi masalah bagi orang miskin adalah masalah mahalnya biaya pelayanan kesehatan. Undang-undang No. 23 tahun 1992 tentang kesehatan banyak mengatur mengenai mutu pelayanan kesehatan di Indonesia termasuk ketentuan masalah biaya perawatan kesehatan. Menurut Undangundang ini biaya perawatan ditentukan oleh pemerintah cq departemen kesehatan.

Bagi golongan masyarakat tertentu biaya rumah sakit yang mahal membuat mereka menjadi takut untuk datang ke rumah sakit, walaupun itu rumah sakit milik pemerintah sekalipun, apalagi rumah sakit swasta. Di lain pihak bagi orang kaya biaya rumah sakit bukan menjadi maslah sama sekali. Bahkan tidak jarang demi untuk mendapatkan perawatan yang lebih baik, orang pergi berobat ke luar negeri untuk mengeboti penyakit yang sebenarnya dapat disembuhkan di dalam negeri.

Fenomena sebagaimana diungkapkan di atas terungkap dari hasil kuesioner yang menyatakan bahwa kriteria rumah sakit yang dipilih oleh pasien kebanyakan (85\%) adalah rumah sakit yang dengan harga/biaya semurah mungkin, sementara pilihan kedua terbanyak adalah rumah sakit dengan fasilitas memadai dan mendukung proses penyembuhan sekalipun harga/biaya mahal (11\%). Sementara rumah sakit yang paling dekat dengan rumah pasien tidak menjadi pilihan utama karena jika rumah sakit yang terdekat dengan pasien tersebut adalah rumah sakit swasta yang mahal, maka pasien yang tidak mampu tetap akan memilih rumah sakit lain yang lebih murah walaupun dengan jarak yang lebih jauh dari tempat tinggalnya (4\%).

Dari hasil kuesioner tersebut dapat diketahui bahwa masalah biaya merupakan pertimbangan utama dari masyarakat sebelum menentukan akan masuk rumah sakit mana. Untuk mengetahui lebih lanjut mengenai masalah tersebut dilakukan wawancara dengan keluarga pasien yang sedang menunggu saudaranya di Rumah Sakit Islam Faisal. Hasil wawancara menunjukan bahwa ketika mengetahui biaya pelayanan paling murah. Dari hasil pemeriksaan Puskesmas diketahui bahwa pasien membutuhkan perawatan yang lebih intensif di rumah sakit yang mempunyai peralatan yang lebih komplit. Ketika memutuskan rumah sakit yang akan dituju pasien dan keluarganya 


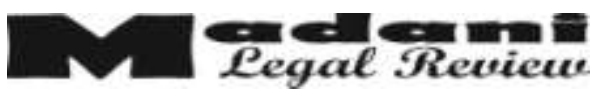

mempertimbangkan masalah biaya sebagai faktor yang paling dominan. Hal ini dikarenakan kemampuan keluarga sangat terbatas, sehingga apabila pasien diobati di rumah sakit yang mahal dikhawatirkan keluarga pasien tidak akan dapat membayar biaya yang dibutuhkan untuk pengobatan yang dilakukan.

Menurut M. Yusuf Saleh, diketahui bahwa di Rumah Sakit Islam Faisal biaya rata-rata pelayanan kesehatan di tentukan berdasarkan standard yang di buat persatuan rumah sakit seluruh Indonesia (PERSIS) dan secara spesifik yang ditentukan sendiri oleh Rumah Sakit Islam Faisal. Tapi realitas di Rumah Sakit Islam Faisal kadang biaya pelayanan kesehatan pada pasien di dasarkan dengan kemampuan ekonomi pasien, apabila si pasien tidak di dasarkan dengan kemampuan ekonomi pasien, apabila si pasien tidak sanggup membayar maka diberikan kebijakan dari pengelola Rumah Sakit.

\section{Kewajiban Hukum Rumah Sakit/ Dokter/ Tenaga Kesehatan Dalam Upaya Pelayanan Kesehatan dan Penyelesaian sangketa.}

Seorang dokter yang profesional diharapkan akan dapat memberikan diagnose yang tepat tentang penyakit yang diderita oleh pasien dan kemudian menetapkan proses pengobatan yang harus dilewati pasien, termasuk menentukan obat yang harus dikonsumsi oleh pasien dalam mengobati penyakitnya tersebut. Seorang dokter juga harus mempunyai keterampilan yang berkaitan dengan upaya pengobatan yang dilakukannya. Keterampilan yang dimaksud antara lain keterampilan melakukan tindakan-tindakan medis yang dibutuhkan, antara lain menjahit luka pasien, keterampilan mengoperasi pasien, keterampilan mempergunakan alat-alat medis, misalnya dokter gigi harus terampil dalam menggunakan alat pencabut gigi atau alat pembersih karang gigi. Apabila dokter memiliki profesionalisme dan keterampilan sebagaimana yang disyaratkan dalam pengobatan penyakit yang diderita pasien, maka ada kemungkinan sembuh cepat dari pasien yng diobati. Sebaliknya apabila dokter tidak memiliki profesionalme dan keterampilan sebagaimana yang disyaratkan dalam mengobati penyakit yang diderita pasien, maka ada kemungkinan bukan kesembuhan yang didapat pasien tetapi pasien dapat bertambah parah, bahkan meninggal dunia.

Setiap hubungan hukum antara satu pihak dengan pihak lainnya dapat mempunyai potensi terjadinya sengketa. Demikian juga halnya dalam pelaksanaan pelayanan jasa kesehatan. Dalam hal ini sebenarnya kedua belah pihak, yaitu 


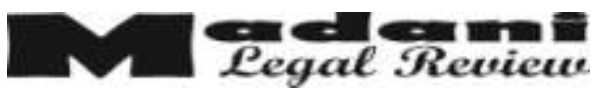

penyelenggara pelayanan kesehatan (rumah sakit/dokter/tenaga kesehatan) dan pengguna pelayanan kesehatan (pasien) sama-sama tidak menginginkan terjadi sengketa. Akan tetapi dalam prakteknya sering kali kedua belah pihak tersebut berada dalam posisi yang berseberangan, yaitu sebagai para pihak dalam sengketa. Untuk menyelesaikan sengketa yang terjadi tersebut ada dua cara yang dapat ditempuh, yaitu melalui jalur keprofesian dan melalui jalur hukum.

Penyelesaian melalui jalur keprofesian adalah melalui MKEK (Majelis Kode Etik Kedokteran), sedangkan penyelesaian melalui jalur hukum adalah melalui jalur litigasi (pengadilan). Dalam hal ini penyelesaian melalui MKEK merupakan upaya penyelesaian secara damai yang biasanya dilakukan dengan cara musyawarah untuk mencapai mufakat. Dalam MKEK ini para pihak dipertemukan dengan ditengahi MKEK. Dalam proses yang dilewati para pihak dipersilahkan mengajukan buktibukti yang dapat memperjelas masalah yang sebenarnya. MKEK bertugas menilai bukti-bukti yang diajukan tersebut dan sejauh mungkin berusaha mendamaikan pihak yang bersengketa tersebut. Apabila masalah yang dimaksud memang timbul karena kelalaian/kesalahan dokter maka MKEK akan memberikan sanksi kepada dokter/tenaga

kesehatan

yang

bersangkutan, misalnya dengan mencabut izin praktek. Di lain pihak apabila masalah tersebut ternyata tidak ada muatan kelalaian/kesalahan sama sekali, maka MKEK akan menjelaskan hal tersebut sehingga para pihak merasa puas.

Sejak berdirinya pada tanggal 24 September 1980 Rumah Sakit Islam Faisal pernah satu kali mempunyai masalah yang diselesaikan dengan prosedur MKEK. Kasus itu terjadi pada tahun 1999 yaitu kasus pengobatan penyakit diare. Penggunaan alat kedokteran yang berupa detektor kanker usus telah mengakibatkan pasien tidak dapat makan dan minum, sehingga membuat tubuh pasien semakin lemah. Pihak keluarga yang menginginkan pertanggungjawaban pihak rumah sakit kemudian mendatangi Rumah Sakit Islam Faisal. Setelah disepakati bahwa permasalahan ini akan diselesaikan melalui MKEK, maka para pihak mengajukan bukti-bukti ke MKEK. Dari bukti yang diajukan diketahui penyebab pasien tidak bisa makan dan minum adalah penggunaan detektor kanker usus telah berubah posisi ususnya, sehingga semua makanan dan minuman yang dimakannya dimuntahkan kembali. Akhirnya MKEK memutuskan pihak Rumah Sakit Islam Faisal harus mengobati pasien sampai sembuh dan semua biaya pengobatan ditanggung pihak 
Rumah Sakit Islam Faisal. Pihak Rumah Sakit Islam Faisal dan keluarga pasien sama-sama menerima keputusan itu, sehingga permasalahan tidak diajukan ke pengadilan.

Penyelesaian melalui MKEK seringkali tidak memuaskan para pihak, dalam hal terjadi demikian maka pihak yang merasa dirugikan dapat membawa tersebut ke pengadilan guna mendapatkan penyelesaian hukum.

Dari hasil penelitian yang dilakukan di Pengadilan Negeri Ujung Padang diketehui bahwa Rumah Sakit Islam Faisal belum pernah dimejahijaukan atas masalah pelayanan kesehatan yang diberikan kepada masyarakat di Kota Ujung Pandang, karena semua masalah yang ada diselesaikan melalui musyawarah secara kekeluargaan. Untuk mengetahui penyebab tidak pernahnya Rumah Sakit Islam Faisal dimejahijaukan oleh pasiennya, penulis melakukan wawancara dengan Kepala Administrasi Rumah Sakit Islam Faisal, Jamaluddin Saleh dapat diketahui bahwa pada umumnya jika terjadi sengketa di Rumah Sakit Islam Faisal maka sejauh mungkin diselesaikan secara kekeluargaan untuk mencapai mufakat dalam rangka mencapai proses penyelesaian sengketa (di luar pengadilan/nonlitigasi). Penyelesaian melalui musyawarah dilakukan sesuai dengan profesi para pihak di Rumah Sakit, jika seorang dokter maka dimusyawarahkan oleh Majelis Kode Etik Kedokteran, apabila pihak pengelolaan Rumah Sakit maka diselesaikan melalui majelis Kode Etik Rumah Sakit dan apabila yang melakukan sengketa adalah perawat/tenaga kesehatan yang lain maka dihadapkan pada Majelis Kode Etik untuk memutuskan sengketa itu, diharapkan keputusan majelis kode etik dapat melindungi hak dan kewajiban para pihak dalam sengketa sehingga keputusan itu tidak merugikan siapapun, akan tetapi kalau musyawarah mufakat tidak menghasilkan keputusan yang baik, bahkan ada pihak yang merasa dirugikan maka silahkan membawa kasus/sengketa itu ke pengadilan untuk diselesaikan secara hukum. Untuk mendapatkan penyelesaian yang optimal, penyelesaian melalui jalur hukum (litigasi) melibatkan kuasa hukum masing-masing pihak.

Menurut dr. Rivai Pakki, dalam memberikan perlindungan hukum bagi kedua belah pihak, maka pihak RS menjalankan tanggungjawab dengan dedikasi yang tinggi. Tanggungjawab dimaksud adalah tanggungjawab umum dan tanggungjawab khusus. Tanggungjawab umum adalah tanggungjawab terhadap masyarakat, sedangkan tanggungjawab khusus adalah kepada dokter/tenaga kesehatan yang 


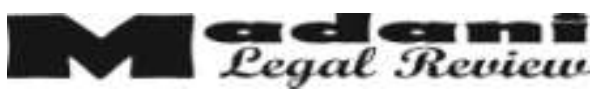

menyelenggarakan pelayanan kesehatan di Rumah Sakit Islam Faisal. Pihak Rumah Sakit harus menjalankan kedua tanggungjawab itu secara seimbang. Di lain pihak menurut dr. A. Baso Sulaeman, Ds. THT, untuk meningkatkan rasa tanggungjawab hukum dan profesi, maka para dokter/tenaga kesehatan harus bekerja sesuai dengan prosedur tetap (protap) yang ditentukan oleh pihak Rumah Sakit Islam Faisal, Ikatan Dokter Indonesia (IDI) dan Departemen Kesehatan.

Hal senada diungkapkan oleh dr. H.A.T. Tjambolang yang merupakan Ketua Komite Medik Rumah Sakit Islam Faisal mengatakan bahwa jalur penyelesaian pertama yang digunakan apabila terjadi sengketa antara pengelola Rumah Sakit atau dokter/tenaga kesehatan dengan pasien untuk menyelesaikan sengketa diluar pengadilan, dengan cara kekeluargaan melalui musyawarah mufakat antara pihak yang bersengketa. Lembaga yang bertugas untuk mengadakan musyawarah adalah komite Medik Rumah Sakit. Komite Medik mempunyai wewenang untuk menyelesaikan setiap sengketa antara para pihak yang terlibat dalam pelayanan kesehatan. Selain itu bertugas mengawasi setiap perilaku dokter/tenaga kesehatan agar tidak menyimpang dari kode etik professional kedokteran. Apabila dalam penyelesaian melalui jalur nonlitigasi masih tidak tercapai kesepakatan, barulah ditempuh jalur hukum (litigasi).

Menurut Jamaluddin Saleh, pedoman pelayanan kesehatan di Rumah Sakit Islam Faisal secara umum diatur dalam Hospital By Law. Dalam menyelesaikan sengketa yang terjadi antara pengelola Rumah Sakit atau dokter/tenaga kesehatan dengan pasien, maka peraturan hukum yang digunakan untuk menyelesaikan sengketa tersebut ada dua macam, yaitu hukum yang bersifat umum, antara lain UU No.23 Th. 1992 dan Peraturan serta Keputusan Menteri Kesehatan, dan hukum yang bersifat khusus, antara lain Pedoman Pelayanan Rumah Sakit, Pedoman Kerja Komite Medik, dan lain-lain.

\section{Perlindungan Hukum Pasien sebagai Konsumen}

Jika dilihat dari uraian di atas dapat diketahui bahwa perlindungan hukum terhadap pasien sebagai konsumen jasa pelayanan kesehatan masih sangat lemah bahkan pengaturan dalam Undang-undang tidak jelas. Pasien yang mengalami penderitaan akibat tindakan medis yang dilakukan oleh dokter/tenaga kesehatan, bahkan ada yang sampai meninggal dunia, ternyata tidak pernah dapat meminta pertanggungjawaban dokter / tenaga kesehatan / rumah sakit yang menanganinya. 
Berdasarkan penelitian yang dilakukan diketahui bahwa tindakan medis yang dilakukan dokter/tenaga kesehatan di Rumah Sakit Islam Faisal sesuai dengan prosedur tetap (protap) tetapi acap kali masih terjadi kelalaian karena ketidakhatihatian dokter/tenaga kesehatan dalam memberikan tindakan medis dan perawatan terhadap pasien. Kelalaian tersebut membuat pihak pasien dirugikan bahkan sampai meninggal dunia. Akan tetapi pihak Rumah Sakit Islam Faisal dengan dokter/tenaga kesehatan yang bertugas senantiasa menyelesaikan masalah tersebut secara kekeluargaan dengan cara membayar ganti rugi. Walaupun telah

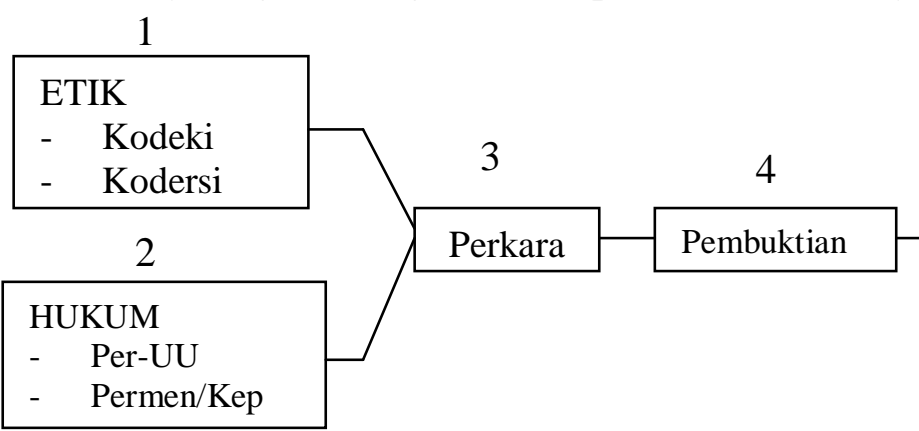

diberikan ganti rugi kepada pasien/ keluarganya, namun aspek perlindungan hukum di Rumah Sakit Islam Faisal masih sangat jauh dari kenyataan pasien/keluarganya belum mendapatkan pertanggungjawaban secara hukum oleh pihak Rumah Sakit Islam Faisal.

Hal ini sangat memprihatinkan, apalagi Undang-undang No. 8 Tahun 1999 tentang Pelindungan Konsumen ternyata tidak berlaku dalam konteks hubungan dokter-pasien.

Lemahnya perlindungan hukum terhadap pasien terlihat dari proses penyelesaian masalah sengketa kesehatan. yang digambarkan dalam bagan berikut.

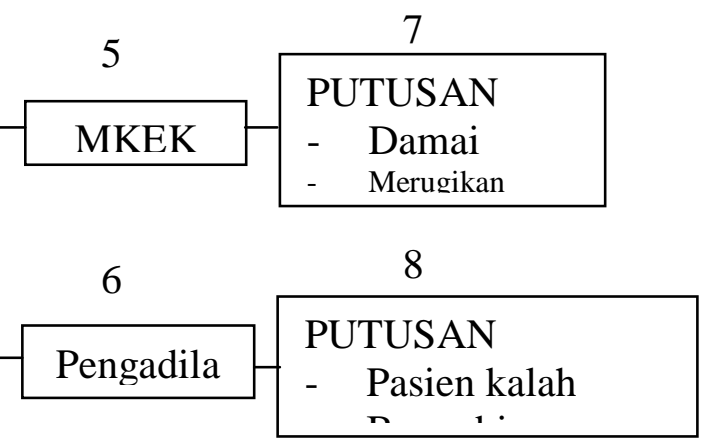

Gambar 1.

Keterangan :

KODEKI : Kode Etik Kedokteran Indonesia

KODERSI : Kode Etik Rumah Sakit Indonesia

MKEK : Majelis Kode Etik Kedokteran

Sumber : Hasil penelitian.

Berdasarkan gambar diatas dapat diketahui bahwa perlindungan hukum terhadap pasien masih lemah disebabkan oleh adanya penerapan asas praduga tak bersalah yang membuat dokter sebagai pihak yang tergugat mempunyai hak untuk tidak dipersalahkan sampai keputusan pengadilan yang mempunyai kekuatan hukum yang tetap. Hal ini juga diatur dalam perundang-undangan tentang 


\section{$M$ m}

kesehatan yang mengatur mengenai hak dan kewajiban dokter sebagai penyelenggara jasa pelayanan kesehatan (lihat proses 1 dan 2).

Sengketa yang dimasukkan ke Pengadilan dapat berbentuk perkara (lihat proses 3). Apapun jenis pengaduan yang diberikan baik perkara maupun gugatan, pihak yang mengadukan (dalam hal ini pasien) diberikan beban untuk membuktikan apa yang dituduhkannya (lihat proses 4). Hal ini sesuai dengan asas hukum di Indonesia yang menyatakan bahwa pihak yang menggugat harus membuktikan bahwa gugatannya adalah benar. Padahal pasien sebagai pihak yang tidak tahu persis mengenai proses medis yang dilakukan terhadap diri/keluarganya sering kali tidak berhasil mengumpulkan bukti yang kuat. Hal ini dikarenakan secara medis, dokterlah yang memegang semua bukti tindakan medis yang dilakukan terhadap pasien. Selama proses pengumpulan bukti yang dilakukan pasien, bisa saja dokter yang digugat/diperkarakan mengganti atau menghilangkan barang bukti karena barang bukti itu memang masih berada di tangannya.

Tidak adanya bukti yang kuat untuk dapat membuat rumah sakit/ dokter/ tenaga kesehatan mempertanggungjawabkan perbuatanya, menbuat sengketa yang diajukan pasien dianggap tidak beralasan.
Dalam keadaan demikain, biasanya penyelesaian yang dilakukan adalah penyelesaian damai dimana pasien menjadi pihak yang dirugikan dalam posisi ini, karena pasien telah dirugikan namun tidak dapat menuntut pihak rumah sakit/dokter/tenaga kesehatan untuk mempertanggungjawabkan perbuatannya. Lebih ironis lagi, apabila kasus dibawa ke pengadilan dan mendapatkan putusan bahwa pasien sebagai penggugat kalah dalam perkara karena tidak dapat mengajukan bukti yang kuat, maka sebagai pihak yang kalah berperkara pasien harus membayar biaya perkara.

Berdasarkan uraian di atas, dapat diketahui betapa lemahnya kedudukan pasien dalam pelaksanaan jasa pelayanan kesehatan. Pasien mengalami kerugian badan (sebagai obyek prosedur pengobatan yang keliru), harus membayar biaya rumah sakit (sebagai konsumen jasa pelayanan kesehatan), harus membuang waktu untuk berperkara di pengadilan, dan harus membayar biaya perkara (sebagai pihak yang kalah dalam persidangan). Betapa banyak kerugian yang dialami pasien sampai sekarang masih terjadi dalam praktek pelayanan kesehatan di Indonesia, temasuk di Rumah Sakit Islam Faisal.

Lemahnya perlindungan hukum terhadap pasien sampai saat ini masih terjadi. Dalam rangka memperkuat 


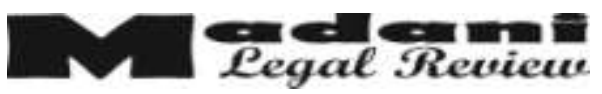

perlindungan hukum terhadap pasien, ada beberapa pihak yang mengusulkan bahwa pasien Rumah Sakit dapat dilindungi dengan Undang-undang No.8 Tahun 1999 tentang Perlindungan Konsumen. Sebagaimana diketahui salah satu hak konsumen yang diatur dalam UUPK adalah hak untuk mendapatkan kompensasi, ganti rugi atau penggantian, apabila barang dan jasa yang diterima tidak sesuai denga perjanjian atau tidak sebagaimana mestinya. Sebaliknya, hak konsumen tadi menjadi kewajiban bagi pelaku usaha. Dengan demikian, pelaku usaha wajib, memberikan suatu jaminan atas barang atau jasa yang diperdagangkan kepada konsumen.

Berdasarkan penelitian yang dilakukan di Rumah Sakit Islam Faisal, diketahui bahwa Rumah Sakit Islam Faisal selaku penyelenggara pelayanan kesehatan bagi masyarakat masih belum menerapkan UU No.8 Tahun 1999 dalam melaksanakan tugas memberikan pelayanan kesehatan kepada masyarakat. Hal ini dikarenakan sampai sekarang masih belum ada ketentuan yang mewajibkan bahwa UU No.8 Tahun 1999 juga berlaku bagi penyelenggara pelayanan kesehatan. Akan tetapi jika pemerintah menerapkan bahwa Undang-undang tersebut berlaku juga bagi pihak penyelenggara pelayanan kesehatan, maka Rumah Sakit Islam Faisal siap melaksanakannya.

Menurut dr.H.A.T. Tjambolang yang merupakan dokter dan Ketua Komite Medik di Rumah Sakit Islam Faisal, dapat diketahui bahwa sebenarnya Undangundang No.8 tahun 1999 tentang perlindungan konsumen dapat diterima sebagai aturan dalam penyelenggaraan upaya pelayanan kesehatan karena sarana kesehatan merupakan institusi produsen jasa pelayanan kesehatan, dimana setiap produsen baik barang maupun jasa tunduk dan menerima ketentuan UU tersebut. Selain itu aturan-aturan yang terdapat dalam undang-undang ini tidak merugikan pihak Rumah Sakit, walaupun pada saat dirumuskan dan ditetapkan tidak melibatkan pengelola Rumah Sakit dan para dokter/tenaga kesehatan sebagai pihak yang mempunyai kompentesi terhadap profesinya. Menurut dr. Rival Pakki, yang juga merupakan dokter di Rumah Sakit Islam Faisal, pembicaraan mengenai kemungkinan diberlakukannya UU No.8 Tahun 1999 dalam jasa pelayanan kesehatan, pernah dibicarakan oleh Ikatan Dokter Indonesia (IDI) pada tahun $2000 \mathrm{di}$ Kota Batu Malang Jawa Timur. Namun demikian masih ada pro dan kontra mengenai hal tersebut.

Namun menurut Daeng Toba selaku pasien di Rumah Sakit Islam Faisal sebagai 
pengguna atau penerima jasa pelayanan kesehatan tidak menerima apabila pasien tersebut sebagai konsumen dengan alasan bahwa apa yang mereka tawarkan kepada Rumah/dokter/tenaga kesehatan bukan barang yang dapat dilihat. Akan tetapi suatu penyakit yang memerlukan pengobatan dan perawatan agar bisa sembuh.

Menurut penulis, lahirnya undangumdang khusus yang mengatur praktek kedokteran sudah sangat urgent. Mengingat, peralatan hukum yang ada saat ini seringkali dinilai berbenturan dengan KEDOKI dan aturan IDI. Acapkali dokter yang diduga melakukan malpraktek diloloskan oleh organisasi profesinya. Hal ini dikarenakan banyak kepentingan yang berkaitan dengan profesi dokter, antara lain penjaga agar dokter tetap dapat dipercaya masyarakat sebagai penyelenggara pelayanan kesehatan.

Selain itu satu permasalahan yang sangat penting dalam perlindungan hukum terhadap pasien menurut penulis adalah pengubah sistem pembuktian dalam proses pembuktian telah terjadinya kesalahan/ kelalaian oleh pihak rumah sakit/dokter/ tenaga kesehatan. Sebagaimana diketahui sistem pembuktian yang digunakan untuk membuktikan kesalahan dokter/tenaga kesehatan dalam melaksanakan pelayanan kesehatan adalah sistem pembuktian kesalahan bahwa dokter dianggap tidak bersalah (presumption of innocent). Berdasarkan asas ini maka dokter berada pada posisi yang lebih unggul daripada pasien, karena selama pasien tidak dapat membuktikan kesalahannya maka kedudukan dokter aman. Dilain pihak adanya beban pembuktian pada pihak penggugat (pasien) juga memperlemah kedudukan pasien, karena semua bukti yang dibutuhkan berada dalam kekuasaan rumah sakit/dokter/tenaga kesehatan. Oleh karena itu dapat dilihat di sini bahwa selama masih menggunakan sistem pembuktian yang lama, maka selamanya kedudukan pasien akan tetap lemah dalam perkara rumah sakit/dokter/tenaga kesehatan-pasien dalam sengketa jasa pelayanan kesehatan.

Berdasarkan hasil penelitian tersebut, kemudian penulis merumuskan ulang proses penyelesaian sengketa jasa pelayanan kesehatan yang memberikan kedudukan seimbang kepada rumah sakit/dokter/tenaga kesehatan-pasien. Proses yang dimaksud adalah : 


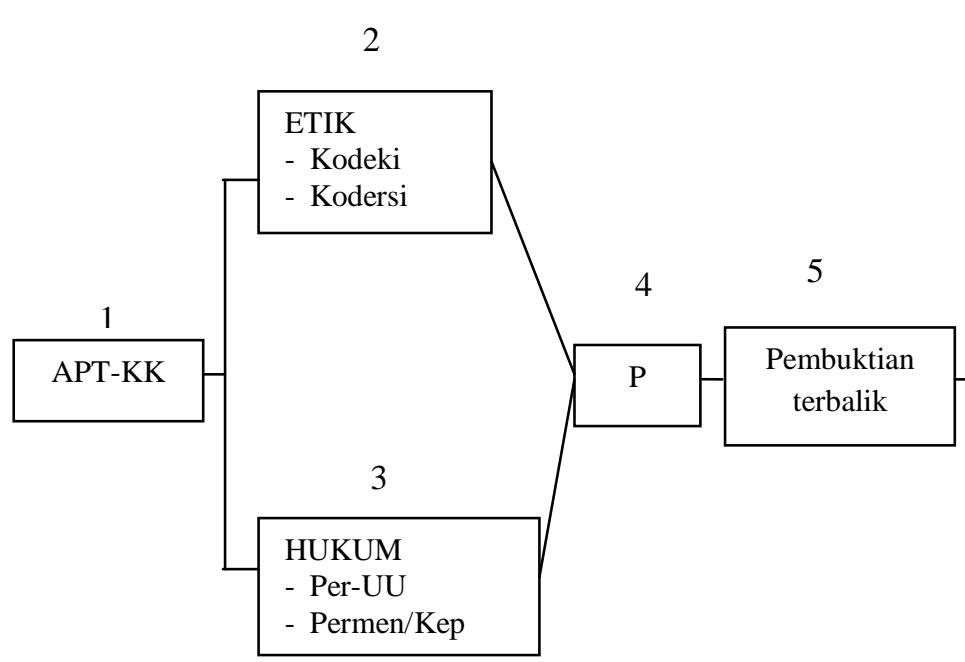

Keterangan :

APT-KK

KODEKI : Kode Etik Kedokteran Indonesia

KODERSI : Kode Etik Rumah Sakit Indonesia

MKEK : Majelis Kode Etik Kedokteran

$\mathrm{P}$

RS/D/TK : : Rumah Sakit/Dokter/Tenaga Kesehatan
$6 \mathrm{~A}$

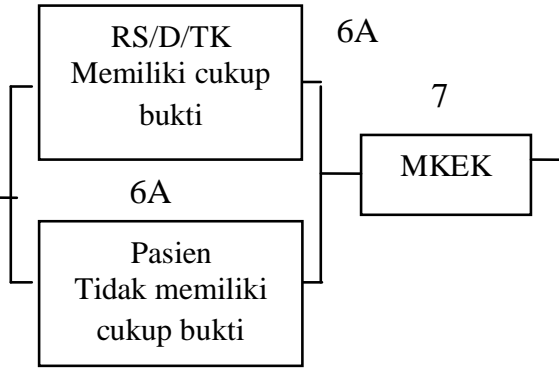

PUTUSAN:

Para Pihak

mendapatkan hak yang

sama dan perlindungan

hukum

9

10

PUTUSAN

Para Pihak

mendapatkan keadilan

kepastian dan

perlindungan hukum

Sumber : Hasil Penelitian.

Berdasarkan gambar 2 di atas dapat diketahui bahwa perubahan yang sangat fundamental dalam usulan perubahan sistem perlindungan hukum terhadap pasien dalam jasa pelayanan kesehatan adalah diubahnya sistem pembuktian, yaitu dari penggunaan asas praduga tak bersalah menjadi asas praduga terjadi kesalahan/kelalaian. Asas praduga terjadi kesalahan/kelalaian dapat diterapkan dengan menggunakan dasar doktrin res ipsa loquintur. Doktrin ini berlaku untuk suatu kesalahan/kelalaian yang sudah sedemikian jelasnya, sehingga orang awam pun tahu bahwa telah terjadi kesalahan/kelalaian (the thing speaks for itself).

Penerapan doktrin ini dalam sengketa jasa pelayanan kesehatan menyebabkan berubahnya pihak yang harus membuktikan dalam penyelesaian sengketa. Jika sebelumnya pihak pasien yang harus membuktikan bahwa telah terjadi kesalahan/kelalaian dalam jasa 
pelayanan kesehatan yang berakibat merugikan pihak pasien, maka dengan menggunakan doktrin ini maka pihak rumah sakit/dokterlah yang bertugas untuk membuktikan bahwa tidak terjadi kesalahan/kelalaian dalam proses jasa pelayanan kesehatan. Dengan kata lain menurut teori baru ini bahwa rumah sakit/dokter/tenaga kesehatan dianggap bersalah sampai mereka dapat membuktikan bahwa mereka tidak bersalah (asas pembuktian terbalik).

Dalam hal ini yang paling penting dalam perlindungan hukum rumah sakit/dokter/tenaga kesehatan dan pasien adalah bahwa Rumah Sakit seharusnya memberikan perlindungan hukum bagi kedua belah pihak, yaitu baik bagi pihak dokter/tenaga kesehatan, maupun terhadap pihak pasien. Menurut dr. Rivai Pakki, dalam perlindungan hukum tersebut pihak Rumah Sakit harus menjalankan tanggungjawab dengan dedikasi yang tinggi. Tanggungjawab dimaksud adalah tanggungjawab umum dan tanggungjawab khusus, karena pihak Rumah Sakit memiliki mitra kerja yakni dokter/tenaga kesehatan harus tunduk dan menjalankan sumpah jabatan dan Undang-undang praktik kedokteran sebagai sebuah tanggungjawab secara universal sehingga semua komponen terlibat di dalamnya. Di lain pihak Rumah Sakit juga menjalankan tanggungjawab terhadap pasien, misalnya ketika seorang pasien masuk di unit gawat darurat, maka ia harus segera diberikan tindakan medis dan pengobatan, sebab jika tidak maka akan fatal akibatnya bagi pasien.

Apa yang diuraikan di atas sejalan dengan pendapat dr. H.A.T. Tjombolang, yang menyatakan tanggungjawab Rumah Sakit ada dua (2) yakni: pertama, tanggungjawab umum yang berkaitan dengan pengelolaan RS baik dari aspek sarana dan prasarana, sumber daya tenaga professional dari pelayanan kedokteran dan aspek-aspek yang lain, jika hal ini berjalan dengan maksimal maka dapat melindungi semua pihak yang terlibat termasuk pasien dan Rumah Sakit serta dokter / tenaga kesehatan. Kedua, tanggungjawab khusus yang berkaitan dengan medik dan hukum, dimana setiap Rumah Sakit memiliki komite medik yang bertanggungjawab jika ada sengketa yang terjadi antara pengelola Rumah Sakit / dokter / tenaga kesehatan dengan Pasien. Dalam hal ini persengketaan antara dokter / tenaga kesehatan dengan pasien itu harus diselesaikan tanpa merugikan semua pihak, sehingga semua merasakan mendapatkan perlindungan hukum.

Lebih jauh lagi bahwa semua aspek perlindungan hukum yang diberikan kepada dokter/tenaga kesehatan dan pasien 


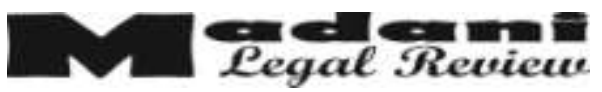

harus dilaksanakan sesuai dengan ketentuan Pasal 28 H UUD 1945 yang berbunyi"setiap orang berhak hidup sejahtera lahir dan batin,bertempat tinggal dan mendapatkan lingkungan hidup yang baik dan sehat serta berhak mendapatkan pelayanan kesehatan". Jika perlindungan hukum yang diberikan kepada pasien sesuai dengan ketentuan tersebut, maka tidak ada terjadi pelanggaran terhadap aspek hukum kesehatan.

\section{KESIMPULAN}

Berdasarkan pembahasan yang telah dilakukan, dapat diambil kesimpulan bahwa sebagai berikut:

Pelindungan hukum terhadap pasien sebagai konsumen jasa pelayanan kesehatan di RSI Faisal Ujung Pandang masih sangat lemah. Hal ini dapat diketahui dari kenyataan bahwa dalam pelaksaan pelayanan kesehatan yang membawah resiko pada kesehatan pasien, bahkan sampai menghilangkan nyawa pasien, hukum sering kali tidak dapat melindungi pihak pasien sebagai pengguna jasa pelayanan kesehatan. Disebabkan karena pihak pasien / keluarganya sangat sulit untuk membuktikan kesalahan / kelalaian yang dilakukan dokter / tenaga kesehatan terhadap memburuknya kondisi kesehatan / meninggalnya pasien. Apabila untuk menuntut pertanggungjawaban hukum pihak Rumah Sakit / dokter / tenaga kesehatan.

Lemahnya perlindungan hukum terhadap pasien disebabkan karena belum ada kesetaraan kedudukan antara pihak pasien selaku pengguna jasa pelayanan kesehatan dengan Rumah Sakit / dokter / tenaga kesehatan selaku penyelenggara jasa pelayanan kesehatan, walaupun menurut ketentuan perundang-undangan seharusnya berlaku prinsip kesetaraan antara kedua belah pihak tersebut di deoan hukum (equality before the law). Lemahnya pelindungan hukum terhadap pasien juga disebabkan karena masih belum adanya Undang-undang Malpraktek yang dapat dijadikan dasar hukum untuk menyelesaikan kasus malpraktek yang dilakukan dokter/tenaga kesehatan. Dilain pihak Undang-undang Kesehatan yang telah ada, yaitu UU No. 23 Th.1992, belum mampu secara tegas menjangkau perbuatan malpraktek dokter/kesehatan yang terjadi.

\section{DAFTAR PUSTAKA}

Adji, Oemar Seno. Etika Profesional dan Hukum Pertanggungjawaban Pidana Dokter ProfesiDokter. Jakarta: Penerbit Erlangga, 1991.

Ameln, fred. Kapita Selekta Hukum Kesehatan. Jakarta : Grafikatama Jaya, 1991.

Azwar, Bahar. Buku Pintar Pasien Sang Dokter. Bekasi : Kesai nt Blanc, 2001. 
Chandrawila Supriadi, Wila, Hukum Kedokteran. Bandung: Penerbit CV. Mandar Maju, 2001.

Hanafiah Jusuf, Muhammad dan Amri Amir-, Etika Kedokteran dan Hukum Kesehatan. Jakarta: Penerbit Buku Kedokteran, 1999.

Kerbala, Husein-, Segi-segi Etis dan Yuridis Informent Consent. Jakarta: Pustaka Sinar Harapan, 1993.

Koeswadji, Hermien Hadiati, Beberapa Permasalahan Hukum dan Medik. Bandung: PT. Citra Aditya Bakti, 1992.
Komalawati, Veronica-, Peranan Informent Consent dalam Transaksi Terapeutik (Persetujuan dalam Hubungan Dokter dan Pasien) Suatu Tinjauan Yuridis. Bandung: Citra Aditya Bakti, 2002.

Mertokusumo, Sudikno-, Mengenal Hukum Suatu Pengantar. Yogyakarta: Penerbit Liberty, 1999. Undang-Undang Dasar Republik Indonesia 1945

Kitab Undang-Undang Hukum Perdata Undang-Undang No. 6 Tahun 1963 tentang Tenaga Kesehatan

Undang-Undang No. 23 Tahun 1992 tentang Kesehatan

Undang-Undang No. 8 Tahun 1999 tentang Perlindungan Konsumen. 